\title{
EVALUASI PEMBELAJARAN PENDIDIKAN AGAMA KRISTEN PADA KURIKULUM 2013
}

\author{
Rinto Hasiholan Hutapea \\ Sekolah Tinggi Agama Kristen Negeri Kupang \\ rintohutapea81@gmail.com
}

\begin{abstract}
Abstact
The discussion in this paper aims to dissect the problems related to the theoretical and practical aspects of learning evaluation in the 2013 Curriculum. In the theoretical aspects the teachers of Christian Religious Education are expected to understand the essence of the evaluation of learning and the nature of the 2013 curriculum. This understanding is important, because of good understanding and right the nature of the evaluation of learning and Curriculum 2013 will help and facilitate Christian Religious Education teachers in designing evaluation instruments for learning in the classroom. On the contrary, if the Christian Education teacher does not understand well the nature of the evaluation of learning and the nature of 2013 Curriculum, it can be ascertained that the Christian Religious Education teacher will have difficulty in designing and implementing classroom learning evaluations.
\end{abstract}

Keywords: evaluation, learning, 2013 curriculum

\begin{abstract}
Abstrak
Pembahasan dalam tulisan ini bertujuan untuk membedah problematika terkait aspek teoritis dan praktis evaluasi pembelajaran pada Kurikulum 2013. Dalam aspek teoritis guruguru PAK diharapkan memahami dengan baik hakikat dari evaluasi pembelajaran dan hakikat Kurikulum 2013. Pemahaman ini penting, karena pemahaman yang baik dan tepat akan hakikat evaluasi pembelajaran dan Kurikulum 2013 akan menolong dan memudahkan guru PAK dalam merancang instrumen evaluasi pembelajaran di kelas. Namun sebaliknya, jika guru PAK tidak memahami dengan baik hakikat evaluasi pembelajaran dan hakikat Kurikulum 2013 dapat dipastikan guru PAK akan mengalami kesulitan dalam merancang dan melaksanakan evaluasi pembelajaran di kelas.
\end{abstract}

Kata kunci: evaluasi, pembelajaran, kurikulum 2013

\section{Pendahuluan}

Evaluasi Pembelajaran merupakan salah satu kompetensi dasar yang harus dimiliki oleh seorang guru dalam menjalankan tanggung jawabnya sebagai pendidik. Kompetensi ini sejalan dengan tugas dan tanggung jawab seorang guru dalam pembelajaran, yaitu mengevaluasi pembelajaran termasuk di dalamnya melaksanakan penilaian hasil belajar. Kompetensi tersebut mencakup instrumen penilaian kemampuan guru dimana salah satu indikatornya adalah 
melakukan evaluasi pembelajaran. ${ }^{1}$ Hal ini selaras dengan Undang-Undang Republik Indonesia Nomor 20 Tahun 2003 tentang Sistem Pendidikan Nasional (Pasal 58) yang menjelaskan bahwa evaluasi hasil belajar peserta didik dilakukan oleh pendidik untuk memantau proses, kemajuan, dan perbaikan hasil belajar peserta didik secara berkesinambungan.

Era globalisasi dewasa ini yang disertai perkembangan informasi, komunikasi, dan teknologi yang begitu cepat menjadikan pendidikan menjadi pusat perhatian. Selain itu, pendidikan menjadi keharusan yang mesti ditempuh. Melihat kondisi ini, menjadikan kompetensi guru dalam melakukan evaluasi pembelajaran juga menjadi sangat penting untuk diperhatikan. Terlebih dalam kaitannya dengan kualitas dan keberhasilan proses pembelajaran yang dilaksanakan di kelas. Terhadap situasi ini, Supardi menegaskan bahwa untuk tercapainya pendidikan yang berkualitas diperlukan guru yang profesional, berkualitas, dan memenuhi kompetensi-kompetensi yang dipersyaratkan."2

Berdasarkan pandangan Supardi di atas, menjadi guru yang profesional dan memiliki kompetensi adalah tuntutan yang tidak terelakkan pada era digitalisasi masa kini. Termasuk di dalamnya kompetensi dan kemampuan guru dalam mengevaluasi pembelajaran. Berkaitan dengan peran strategis guru ini, menunjukkan bahwa peran guru dalam melaksanakan evalusi pembelajaran bukanlah pekerjaan yang mudah atau gampangan. Namun sebaliknya, melaksanakan evaluasi pembelajaran adalah keharusan dan memerlukan perhatian serta penanganan yang serius.

Kompetensi guru dalam melaksanakan evaluasi pembelajaran erat kaitannya dengan pengembangan keprofesian guru. Seperti yang diungkapkan oleh Wirman Kasmayadi, Kumaidi, dan Sumarno. ${ }^{3}$ Mereka menjelaskan bahwa pengembangan keprofesian berkelanjutan guru secara personal berorientasi pada pemeliharaan, peningkatan, atau perluasan kompetensi. Guru harus belajar secara berkelanjutan agar dapat memperbarui pengetahuan dan keterampilannya dengan belajar strategi, teknik, dan metode baru untuk memenuhi tantangan kelas baru, memperbaiki diri dan mengubah sekolah menjadi masyarakat belajar, serta dapat merespon perubahan pendidikan. Gagasan pengembangan keprofesian guru ini menunjukkan bahwa guru sangat penting dalam mengembangkan kompetensi diri.

Pemahaman yang baik akan konsep evaluasi pembelajaran sangat penting bagi guru. Apabila konsep ini tidak dapahami dengan baik, maka akan muncul permasalahan dan kekeliruan dalam melaksanakannya. Berikut ini beberapa problematika dalam memahami konsep evaluasi pembelajaran baik secara teoritis maupun praktis. Pertama, secara teoritis. Secara teoritis masih muncul beberapa perbedaan pemahaman tentang istilah evaluasi pembelajaran. Misalnya saja, ada yang memahami istilah evaluasi, pengukuran, dan penilaian adalah memiliki makna yang sama. Seperti yang diungkapkan oleh Suharsimi Arikunto sebagai berikut: "Sementara orang memang lebih cenderung mengartikan ketiga kata tersebut sebagai suatu pengertian yang sama sehingga dalam penggunaannya hanya tergantung dari kata mana yang siap untuk diucapkan dan sementara

1 Zainal Arifin, Modul Evaluasi Pembelajaran (Jakarta: Direktorat Jenderal Pendidikan Islam Kementerian Agama RI, 2012), 3.

2 Supardi, Kinerja Guru (Jakarta: RajaGrafindo Persada, 2013), 8.

3 Wirman Kasmayadi, Kumaidi, dan Sumarno, "Pengembangan Instrumen Asesmen Diri Guru Terhadap Aktivitas Pengembangan Keprofesian Berkelanjutan" https://journal.uny.ac.id/index.php/jpep/article/view/8290/10888 (diakses 9 Maret 2019). 
orang yang lainnya membedakan ketiga istilah tersebut." 4 Demikian halnya dengan penuturan Farida Yusuf Tayibnapis. Ia mengungkapkan biasanya evaluasi pendidikan selalu dihubungkan dengan hasil belajar, namun saat ini konsep evaluasi mempunyai arti yang lebih luas daripada itu. ${ }^{5}$

Pandangan tentang konsep evaluasi di atas menunjukkan bahwa masih terdapat perbedaan pemahaman tentang konsep evaluasi. Untuk itu, secara teoritis penelitian ini mencoba untuk memberikan penjelasan yang tepat tentang konsep evaluasi pembelajaran.

Kedua, aspek praktis. Aspek praktis berkaitan dengan sejauh mana guru-guru dalam proses pembelajaran mengaplikasikan dan mengejewantakan evaluasi pembelajaran sesuai dengan ketentuan dan kaidah yang berlaku. Misalnya saja, dalam suatu proses evaluasi pembelajaran di kelas, hasil evaluasi dijabarkan dalam bentuk nilai, maka anak yang mendapat nilai tinggi disebut pintar atau cerdas, sedangkan anak yang nilainya rendah disebut lambat belajar (bahasa halus dari istilah bodoh). Dengan demikian makna evaluasi berubah menjadi tindakan menghakimi, memvonis, dan menyalahkan siswa. ${ }^{6}$ Hal ini dipertegas oleh Tayibnapis, yang mengatakan bahwa definisi evaluasi yang menghakimi (judgmental definition of evaluation) menurut kelompok konsorsium Evaluasi Standford menolak definisi evaluasi menghakimi. Karena menurut mereka bukanlah tugas evaluator menentukan apakah suatu program berguna atau tidak. Evaluator tidak dapat bertindak sebagai wasit terhadap orang lain.

Beranjak dari persoalan-persoalan di atas, mempertegas bahwa pelaksanaan evaluasi pembelajaran masih menjadi pergelutan di antara guruguru pada umumnya, serta guru-guru Pendidikan Agama Kristen (PAK) secara khusus. Pergulatan ini berlanjut pada penyesuaian perencanaan pembelajaran pada Kurikulum 2013, yang mana perlu strategi dan persiapan khusus untuk melaksanakannya. Tantangan guru PAK ini menjadi fokus perhatian dalam tulisan ini, yang mana tugas dalam mengevaluasi pembelajaran mesti disesuaikan dengan tuntutan Kurikulum terbaru.

Tugas mengevaluasi pembelajaran pada mata pelajaran PAK tentu tidak mudah. Butuh persiapan, pembelajaran, dan penyesuaian dalam menyusun pembelajaran yang sesuai dengan tuntutan Kurikulum 2013. Untuk itu, penulis melalui tulisan ini mencoba menawarkan pendekatan-pendekatan efektif kepada guru-guru PAK dalam melaksanakan evaluasi pembelajaran sesuai tuntutan Kurikulum 2013.

\section{Metode}

Tulisan ini lahir dan dituntaskan oleh perenungan-perenungan teoritis berdasarkan studi kepustakaan. Melalui tulisan ini diharapkan permasalahan-permasalahan teoritis tentang evaluasi pembelajaran PAK dapat teratasi. Terutama berkaitan dengan penyesuaian evaluasi pembelajaran yang sesuai dengan tuntutan Kurikulum 2013. Melalui tulisan ini juga diharapkan menjadi pertimbangan untuk melaksanakan penelitian lebih lanjut dengan metode yang berbeda, seperti riset lapangan. Sehingga ditemukan permasalahan yang lebih detail dan solusi yang lebih efektif terkait pelaksanaan evaluasi pembelajaran PAK yang sesuai tuntutan Kurikulum 2013.

\footnotetext{
4 Suharsimi Arikunto, Dasar-dasar Evaluasi Pendidikan Edisi 2 (Jakarta: Bumi Aksara, 2012), 1.

5 Farida Yusuf Tayibnapis, Evaluasi Program dan Instrumen Evaluasi (Jakarta: Rineka Cipta, 2008), 3 .

6 Tuanguru, "Evaluasi Bukan Untuk Menghakimi Siswa" http://www.tuanguru.com/2012/07/evaluasi-bukan-untuk-menghakimi-siswa.html (diakses 5 Februari 2019).
} 


\section{Hasil dan Pembahasan}

Tesis dalam tulisan ini adalah pemahaman yang tepat akan evaluasi pembelajaran PAK, maka pelaksanaannya pun akan tepat. Terlebih pemahaman yang tepat akan evaluasi pembelajaran PAK dibarengi ketepatan dalam membaca tuntutan Kurikulum 2013. Untuk mencapai sasaran tersebut, penulis akan mengawalinya dengan memaparkan secara teoritis konsep evaluasi pembelajaran PAK dan Kurikulum 2013.

1. Evaluasi Pembelajaran PAK

Secara teori evaluasi pembelajaran erat kaitannya dengan istilah tes, pengukuran, penilaian, dan evaluasi itu sendiri. Untuk memahami arti evaluasi pembelajaran, penulis akan menyajikan terlebih dahulu pengertian dari keempat istilah tersebut. Pertama, tes. Tes pada hakikatnya adalah suatu alat yang berisi serangkaian tugas yang harus dikerjakan atau soal-soal yang harus dijawab oleh peserta didik untuk mengukur suatu aspek perilaku tertentu. ${ }^{7}$ Artinya, fungsi tes adalah sebagai alat ukur. Dalam tes prestasi belajar, aspek perilaku yang hendak diukur adalah tingkat kemampuan peserta didik dalam menguasai materi pelajaran yang telah disampaikan.

Kedua, pengukuran. Pengukuran adalah suatu proses atau kegiatan untuk menentukan kuantitas daripada sesuatu. ${ }^{8}$ Kata "sesuatu" bisa berarti peserta didik, guru, gedung sekolah, meja belajar, white board, dan sebagainya. Dalam proses pengukuran, tentu guru harus menggunakan alat ukur (tes atau non-tes). Alat ukur tersebut harus standar, yaitu memiliki derajat validitas dan reliabilitas yang tinggi. Dalam bidang pendidikan, psikologi, maupun variabel-variabel sosial lainnya, kegiatan pengukuran biasanya menggunakan tes.

Ketiga, penilaian. Dalam hubungannya dengan proses dan hasil belajar, penilaian dapat didefinisikan sebagai suatu proses atau kegiatan yang sistematis dan berkesinambungan untuk mengumpulkan informasi tentang proses dan hasil belajar peserta didik dalam rangka membuat keputusan-keputusan berdasarkan kriteria dan pertimbangan tertentu. ${ }^{9}$

Keempat, evaluasi. Evaluasi adalah suatu proses yang sistematis dan berkelanjutan untuk menentukan kualitas (nilai dan arti) daripada sesuatu, berdasarkan pertimbangan dan kriteria tertentu untuk membuat suatu keputusan. ${ }^{10}$

Pemahaman akan keempat istilah di atas sangat penting buat guru PAK dalam membedakan dan memahami konsep dasar evaluasi pembelajaran. Berkaitan dengan makna evaluasi pembelajaran, istilah evaluasi sudah dijelaskan pada salah satu istilah-istilah di atas. Evaluasi pembelajaran terdiri atas dua kata, yaitu "evaluasi" dan "pembelajaran." Evaluasi artinya suatu proses yang sistematis dan berkelanjutan untuk menentukan kualitas (nilai dan arti) daripada sesuatu, berdasarkan pertimbangan dan kriteria tertentu untuk membuat suatu keputusan.

Sementara itu, untuk kata "pembelajaran" memiliki pengertian sebagai berikut. Dalam arti sempit pembelajaran dapat diartikan sebagai suatu proses atau cara yang dilakukan agar seseorang dapat melakukan kegiatan belajar, sedangkan belajar adalah suatu proses perubahan tingkah laku karena interaksi individu dengan lingkungan dan

7 Zainal Arifin, Evaluasi Pembelajaran: Prinsip, Teknik, dan Prosedur (Bandung: Remaja Rosdakarya, 2016) , 3.

8 Ibid., 4.

9 Ibid.

10 Ibid., 5. 
pengalaman. ${ }^{11}$ Lebih lanjut, istilah "pembelajaran" (instruction) berbeda dengan istilah "pengajaran" (teaching). Kata "pengajaran" lebih bersifat formal dan hanya ada di dalam konteks guru dengan peserta didik di kelas, sedangkan kata "pembelajaran" tidak hanya ada dalam konteks guru dengan peserta didik di kelas secara formal, tetapi juga meliputi kegiatan-kegiatan belajar peserta didik di luar kelas yang mungkin saja tidak dihadiri oleh guru secara fisik.

Sukardi lebih lanjut menjelaskan bahwa evaluasi pembelajaran merupakan inti bahasan evaluasi yang kegiatannya dalam lingkup kelas atau lingkup proses belajar mengajar. ${ }^{12}$ Dengan demikian, evaluasi pembelajaran adalah suatu proses atau kegiatan yang sistematis, berkelanjutan, dan menyeluruh dalam rangka pengendalian, penjaminan, dan penetapan kualitas (nilai dan arti) berbagai komponen pembelajaran berdasarkan pertimbangan dan kriteria tertentu sebagai bentuk pertanggungjawaban guru dalam melaksanakan pembelajaran.

Selain pengertian evaluasi pembelajaran di atas, seorang guru PAK juga perlu memahami dengan baik prinsip-prinsip dasar dari evaluasi pembelajaran. Berikut ini terdapat beberapa prinsip dasar dari evaluasi pembelajaran. ${ }^{13}$

a. Kontinuitas

Evaluasi tidak boleh dilakukan secara incidental karena pembelajaran itu sendiri adalah suatu proses yang kontinu. Oleh sebab itu, evaluasi pun harus dilakukan secara kontinu. Hasil evaluasi yang diperoleh pada suatu waktu harus senantiasa dihubungkan dengan hasil-hasil pada waktu sebelumnya, sehingga dapat diperoleh gambaran yang jelas dan berarti tentang perkembangan peserta didik.

b. Komprehensif

Dalam melakukan evaluasi terhadap suatu objek, guru harus mengambil seluruh objek itu sebagai bahan evaluasi. Misalnya, jika objek evaluasi itu adalah peserta didik, maka seluruh aspek kepribadian peserta didik itu harus dievaluasi, baik menyangkut kognitif, afektif maupun psikomotor. Begitu juga dengan objek-objek evaluasi lainnya.

c. Adil dan Objektif

Dalam melaksanakan evaluasi, guru harus berlaku adil tanpa pilih kasih. Semua peserta didik harus diperlakukan sama tanpa "pandang bulu." Guru juga hendaknya bertindak secara objektif, apa adanya sesuai dengan kemampuan peserta didik. Evaluasi harus didasarkan atas kenyataan (data dan fakta) yang sebenarnya, bukan hasil manipulasi atau rekayasa.

d. Kooperatif

Dalam kegiatan evaluasi guru hendaknya bekerja sama dengan semua pihak, seperti orang tua peserta didik, sesame guru, kepala sekolah, termasuk dengan peserta didik itu sendiri. Hal ini dimaksudkan agar semua pihak merasa puas dengan hasil evaluasi, dan pihak-pihak tersebut merasa dihargai.

e. Praktis

Praktis mengandung arti mudah digunakan, baik oleh guru itu sendiri yang menyusun alat evaluasi maupun orang lain yang akan menggunakan alat tersebut. Untuk itu harus diperhatikan bahasa dan petunjuk mengerjakan soal.

Konsep pemahaman berikutnya yang perlu diperhatikan oleh guru PAK dalam memahami evaluasi pembelajaran adalah berkaitan dengan tujuan dan fungsi evaluasi pembelajaran itu sendiri. Berikut ini akan dipaparkan secara singkat tujuan dan fungsi

11 Ibid., 10.

12 Sukardi, Evaluasi Pendidikan: Prinsip dan Operasionalnya (Jakarta: Bumi Aksara, 2011), 5.

13 Arifin, Evaluasi Pembelajaran: Prinsip, Teknik, dan Prosedur, 31. Lihat juga, Sukardi, Evaluasi Pendidikan: Prinsip dan Operasionalnya, 4-5. 
evaluasi pembelajaran. Pertama, tujuan evaluasi pembelajaran. Tujuan evaluasi pembelajaran adalah untuk mengetahui keefektifan dan efisiensi sistem pembelajaran, baik yang menyangkut tentang tujuan, materi, metode, media, sumber belajar, lingkungan maupun sistem penilaian itu sendiri. ${ }^{14}$

Kedua, fungsi evaluasi pembelajaran. Zainal Arifin mengemukakan beberapa fungsi evaluasi sebagai berikut:15 1) Secara psikologis, peserta didik selalu butuh untuk mengetahui sejauh mana kegiatan yang telah dilakukan sesuai dengan tujuan yang hendak dicapai. 2) Secara sosiologis, evaluasi berfungsi untuk mengetahui apakah peserta didik sudah cukup mampu untuk terjun ke masyarakat. 3) Secara didaktis-metodis, evaluasi berfungsi untuk membantu guru dalam menempatkan peserta didik pada kelompok tertentu sesuai dengan kemampuan dan kecakapannya masing-masing serta membantu guru dalam usaha memperbaiki proses pembelajarannya. 4) Evaluasi berfungsi untuk mengetahui kedudukan peserta didik dalam kelompok, apakah dia termasuk anak yang pandai, sedang atau kurang pandai. 5) Evaluasi berfungsi untuk mengetahui taraf kesiapan peserta didik dalam menempuh program pendidikannya. 6) Evaluasi berfungsi membantu guru dalam memberikan bimbingan dan seleksi, baik dalam rangka menentukan jenis pendidikan, jurusan, maupun kenaikan kelas. 7) Secara administratif, evaluasi berfungsi untuk memberikan laporan tentang kemajuan peserta didik kepada orang tua, pejabat pemerintah yang berwenang, kepala sekolah, guru-guru, dan peserta didik itu sendiri.

Pemahaman yang baik tentang tujuan dan fungsi evaluasi pembelajaran ini sangat penting bagi seorang guru PAK. Hal ini terkait dengan upaya yang akan dilaksanakan oleh guru PAK dalam mengevaluasi proses-proses pembelajaran yang telah dilakukan oleh guru di kelas. Upaya pelaksanaan evaluasi pembelajaran tersebut apakah sudah sesuai dengan tujuan pembelajaran yang sudah ditetapkan pada rancangan pembelajaran sebelumnya atau tidak. Dengan demikian, pemahaman yang tepat akan konsep evaluasi pembelajaran akan menolong guru PAK dalam melaksanakan evaluasi pembelajaran di kelas.

Hal penting lainnya yang perlu diperhatikan oleh guru PAK adalah menghubungkan pelaksanaan evaluasi pembelajaran dengan hakikat dari PAK itu sendiri. Hakikat PAK berkaitan dengan pemahaman akan pengertian dan tujuan PAK itu sendiri. Secara teoritis, Robert R. Boehlke dalam bukunya Sejarah Perkembangan Pemikiran dan Praktek PAK dari Plato sampai Ig. Loyola mengutip pernyataan Martin Luther (14831548) menjelaskan pengertian PAK adalah sebagai berikut: "Pendidikan yang melibatkan warga jemaat untuk belajar teratur dan tertib agar semakin menyadari dosa mereka serta bersukacita dalam firman Yesus Kristus yang memerdekakan. Pendidikan Agama Kristen berfungsi untuk memperlengkapi mereka dengan sumber iman, khususnya yang berkaitan dengan pengalaman berdoa, firman dan rupa-rupa kebudayaan sehingga mereka mampu melayani sesamanya termasuk masyarakat dan negara serta mengambil bagian dengan bertanggung jawab dalam persekutuan Kristen." 16

Sementara itu, menurut Paulus L. Kristianto dalam bukunya Prinsip dan Praktik Pendidikan Agama Kristen mengutip pernyataan Werner C. Graendorf (1976) menguraikan pengertian PAK berikut: "Pendidikan Agama Kristen adalah proses pengajaran dan pembelajaran yang berdasarkan Alkitab, berpusat pada Kristus, dan bergantung pada kuasa Roh Kudus, yang membimbing setiap pribadi pada semua tingkat pada

14 Ibid., 14.

15 Ibid., 16-18.

16 Robert R. Boehlke, Sejarah Perkembangan Pemikiran dan Praktek PAK dari Plato sampai Ig. Loyola (Jakarta : BPK Gunung Mulia, 1994), 342. 
pertumbuhan, melalui pengajaran masa kini kearah pengenalan dan pengalaman rencana dan kehendak Allah melalui Kristus dalam setiap aspek kehidupan, dan memperlengkapi mereka bagi pelayanan yang efektif, yang berpusat pada Kristus sang Guru Agung dan perintah yang mendewasakan para murid."17

Secara sederhana, pengertian PAK adalah proses pengajaran dan pembelajaran yang berdasarkan Alkitab, berpusat pada Kristus, dan bergantung pada kuasa Roh Kudus, sehingga mampu melayani sesamanya termasuk masyarakat dan negara serta mengambil bagian dengan bertanggung jawab dalam persekutuan Kristen.

Sedangkan tujuan dari PAK adalah sebagai berikut: ${ }^{18}$ a) Menghasilkan manusia yang dapat memahami kasih Allah didalam Yesus Kristus dan mengasihi Allah dan sesama. b) Menghasilkan manusia Indonesia yang mampu menghayati imannya secara bertanggungjawab serta berakhlak mulia dalam masyarakat majemuk. Lebih lanjut, Daniel Numahara menambahkan bahwa tujuan PAK adalah untuk mengajak, membantu, menghantar seseorang untuk mengenal kasih Allah yang nyata dalam Yesus Kristus, sehingga dengan pimpinan Roh Kudus ia datang ke dalam persekutuan yang hidup dengan Tuhan. Hal tersebut dinyatakan dalam kasihnya terhadap Allah dan sesama, yang dihayati dalam hidupnya sehari-hari, baik dengan kata-kata maupun perbuatan selaku anggota tubuh Kristus.

Hakikat PAK ini menjadi dasar buat guru dalam merumuskan dan melaksanakan evaluasi pembelajaran di kelas. Tugas selanjutnya yang perlu dilaksanakan oleh seorang guru PAK adalah mempelajari dan menghubungkan materi pelajaran dengan kurikulum yang digunakan dan diterapkan di sekolah.

\section{PAK Dalam Kurikulum 2013}

Berikut ini ringkasan penjelasan PAK dalam Kurikulum 2013 yang dikeluarkan oleh Kementerian Pendidikan dan Kebudayaan RI tahun 2013.19 Dijelaskan bahwa tiap ruang lingkup PAK, yaitu PAK di gereja, PAK dalam keluarga dan PAK di sekolah dan perguruan tinggi memiliki ciri khas masing-masing. Adapun PAK di sekolah lebih terfokus pada pemahaman akan nilai-nilai kristiani dan perwujudannya dalam kehidupan Allah Tritunggal dan karya-karya-Nya serta nilai-nilai. Hal ini penting mengingat PAK merupakan bagian integral sistem pendidikan Indonesia dengan sendirinya membawa sejumlah konsekuensi antara lain harus bersinggungan dengan pergumulan bangsa dan negara. Oleh karena itu, melalui pendekatan nilai-nilai iman diharapkan anak-anak Kristen bertumbuh sebagai anak Kristen Indonesia yang sadar akan tugas dan kewajibannya sebagai warga gereja dan warga masyarakat yang bertanggung jawab.

Berdasarkan kerangka berpikir di atas, maka pembelajaran PAK di sekolah diharapkan mampu menghasilkan sebuah proses transformasi pengetahuan, nilai, dan sikap. Hal itu memperkuat nilai-nilai kehidupan yang dianut oleh siswa terutama dengan dipandu oleh ajaran Iman Kristen, sehingga siswa mampu menunjukkan kesetiaannya kepada Allah, menjunjung tinggi nasionalisme dengan taat kepada Pancasila dan UUD 1945.

17 Kristianto, Prinsip E Praktik Pendidikan Agama Kristen (Jakarta : BPK Gunung Mulia, 2000),

4.

18 Daniel Nuhamara, Pembimbing Pendidikan Agama Kristen (Bandung : Jurnal Info Media, 2009), 31.

19 Kemendikbud, Buku Guru Pendidikan Agama Kristen dan Budi Pekerti (Jakarta: Kementerian Pendidikan dan Kebudayaan, 2014), 14-15. 
Pembahasan isi kurikulum selalu dimulai dari lingkup yang paling kecil, yaitu diri peserta didik sebagai ciptaan Allah, kemudian keluarga, teman, lingkungan di sekitar peserta didik, masyarakat di lingkungan sekitar dan bangsa Indonesia serta dunia secara keseluruhan dengan berbagai dinamika persoalan. Pola pendekatan ini secara konsisten nampak pada jenjang SD sampai SMA/SMK.

Materi dan metodologi pengajaran PAK serta disiplin ilmu psikologi membantu perkembangan psikologis peserta didik dengan baik. PAK disusun sedemikian rupa dengan tidak melupakan karakteristik perkembangan psikologis peserta didik. Materi PAK disesuaikan dengan kebutuhan psikologis peserta didik, sehingga tujuan materi dapat dicapai secara maksimal. Metodologi pun hendaknya memperhatikan karakteristik peserta didik, sehingga tumbuh kembang anak secara kognitif, afektif, psikomotorik, dan spiritual anak terjadi dengan baik. Dalam istilah lain disebut Cipta, Rasa, dan Karsa.

Tujuan yang ingin dicapai melalui PAK yang dilaksanakan di sekolah-sekolah adalah terjadinya transformasi dan internalisasi nilai-nilai kristiani bagi para peserta didik. Dengan kata lain PAK merupakan pendidikan nilai, sehingga diharapkan melaluinya terjadi perubahan dan pembaruan baik pemahaman maupun sikap dan perilaku. Baik pendidikan agama maupun pengajaran agama yang bersifat dogmatis-etis sesungguhnya merupakan tanggung jawab keluarga dan gereja. Transformasi dan internalisasi nilai-nilai kristiani bagi para peserta didik juga dapat difasilitasi oleh para pendidik PAK. Dengan kata lain PAK merupakan pendidikan nilai, sehingga diharapkan melaluinya terjadi perubahan dan pembaruan, baik tentang pemahaman maupun sikap dan perilaku.

Pemaparan PAK pada kurikulum 2013 di atas menunjukkan bahwa pengejewantahan nilai-nilai kristiani dalam kehidupan sehari-hari menjadi poin penting yang mesti diperhatikan oleh guru. Pengejewantahan nilai-nilai kristiani tersebut diharapkan tercermin dalam sikap dan perilaku peserta didik ketika berada di tengahtengah masyarakat. Untuk itu, kajian-kajian evaluasi pembelajaran yang dilaksanakan oleh guru PAK diharapkan juga mengacu pada tuntutan nilai-nilai kristiani yang tertuang dalam Kurikulum 2013.

Guru PAK dalam melaksanakan evaluasi pembelajaran sesuai tuntutan Kurikulum 2013, sekiranya perlu juga memahami hakikat dari kurikulum itu sendiri. Berikut ini beberapa keterangan terkait Kurikulum 2013. Pertama, ciri khas Kurikulum 2013. Kurikulum 2013 memiliki ciri khas sebagai berikut:20 1) Tiap mata pelajaran mendukung semua kompetensi (sikap, keterampilan, dan pengetahuan) yang terkait satu dengan yang lain serta memiliki kompetensi dasar yang diikat oleh kompetensi inti tiap kelas. 2) Konsep dasar pembelajaran mengedepankan pengalaman individu melalui observasi (meliputi menyimak, melihat, membaca, mendengarkan), bertanya, asosiasi, menyimpulkan, mengkomunikasikan, menalar, dan berani bereksperimen yang tujuan utamanya adalah untuk meningkatkan kreativitas anak didik. Selain itu proses pembelajaran juga diarahkan untuk membiasakan anak didik beraktivitas secara kolaboratif dan berjejaring untuk mencapai suatu kemampuan yang harus dikuasai oleh anak didik pada aspek pengetahuan (kognitif) yang meliputi daya kritis dan kreatif, kemampuan analisis dan evaluasi. Sikap (afektif), yaitu religiusitas, mempertimbangkan nilai-nilai moralitas dalam melihat sebuah masalah, mengerti dan toleran terhadap perbedaan pendapat. Keterampilan (psikomotorik) meliputi terampil berkomunikasi, ahli dan terampil dalam bidang kerja. 3) Pendekatan pembelajaran adalah student centered artinya proses pembelajaran berpusat pada siswa/anak didik, guru berperan sebagai fasilitator atau pendamping dan pembimbing

${ }^{20}$ Ibid., 8-9. 
siswa dalam proses pembelajaran. Selain itu dikenal sebagai active and cooperative learning yaitu dalam proses pembelajaran siswa harus aktif untuk bertanya, mendalami, dan mencari pengetahuan untuk membangun pengetahuan mereka sendiri melalui pengalaman dan eksperimen pribadi dan kelompok, metode observasi, diskusi, presentasi, melakukan proyek sosial dan sejenisnya. Bersifat contextual, yaitu pembelajaran harus mengaitkan dengan konteks sosial di mana anak didik/siswa hidup, yaitu lingkungan kelas, sekolah, keluarga, dan masyarakat. Melalui pendekatan ini diharapkan dapat menunjang capaian kompetensi anak didik secara optimal. 4) Penilaian untuk mengukur kemampuan pengetahuan, sikap, dan keterampilan hidup siswa yang diarahkan untuk menunjang dan memperkuat pencapaian kompetensi yang dibutuhkan oleh anak didik di abad ke-21. Dengan demikian, penilaian yang dilakukan sebagai bagian dari proses pembelajaran adalah penunjang pembelajaran itu sendiri. Dengan proses pembelajaran yang berpusat pada siswa, maka sudah seharusnya penilaian juga dapat dikreasi sedemikian rupa hingga menarik, menyenangkan, tidak menegangkan, dapat membangun rasa percaya diri dan keberanian siswa dalam berpendapat, serta membangun daya kritis dan kreativitas.

Kedua, aspek positif Kurikulum 2013. Kurikulum 2013 memiliki aspek-aspek positif, di antaranya:21 1) Aspek Konsep Dasar, yaitu menyikapi dokumen penyempurnaan kurikulum 2013, secara konseptual kurikulum 2013 dicanangkan dengan memperhatikan kondisi ekonomi, politik, sosial, dan budaya, serta pesatnya perkembangan IPTEKS yang melanda seluruh lini kehidupan individu sampai pada kehidupan berbangsa dan bernegara. Jadi sepantasnya dilakukan penyempurnaan kurikulum. 2) Aspek Orientasi, yaitu secara konseptual terjadinya peningkatan dan keseimbangan antara kompetensi sikap (attitude), keterampilan (skill) dan pengetahuan (knowledge), serta tidak melepaskan diri nilai-nilai budaya, baik yang ada secara kedaerahan, maupun kebudayaan secara nasional. 3) Aspek Daya Saing, yaitu penyempurnaan kurikulum dimaksudkan untuk meningkatkan kompetensi untuk dapat meningkatkan kualitas pendidikan Indonesia yang berada pada "peringkat bawah" dalam dunia internasional. Hal ini sejalan dengan amanat UU No 20 tahun 2003 sebagaimana tersurat dalam penjelasan pasal 35: kompetensi lulusan merupakan kualifikasi kemempuan lulusan yang mencakup sikap, pengetahuan, dan keterampilan sesuai dengan standar nasional yang telah disepakati. Hal ini sejalan pula dengan pengembangan KBK dan KTSP. 4) Pendekatan Tematik Integratif yang akan dikembangkan tentu sangat menarik untuk diperbincangkan. Sudah tidak ada lagi konsepsi mata pelajaran, sebab mata pelajaran sudah terintegrasi di dalam tema-tema. Jadilah temalah yang menentukan bukan lagi satuan-satuan mata pelajaran.

Ketiga, kekurangan Kurikulum 2013. Guru PAK juga perlu memahami beberapa kekurangan dari Kurikulum 2013 sehingga mengalami revisi. Berikut ini dikemukakan beberapa kekurangan kurikulum 2013, yakni:22 1) Penyempurnaan dan kurikulum 2013 terkesan tergesa-gesa tanpa dibarengi dengan perencanaan dan pemikiran yang bulat. Hal ini dapat dibuktikan dengan beberapa alasan, yakni: (1) KTSP yang digulirkan Tahun 2006, yang belum sempat dilaksanakan dengan tuntas, tiba-tiba dengan bergantinya menteri berganti pula kurikulum; dan (2) penyediaan buku ajar atau buku pelajaran dalam waktu yang relatif pendek. Dapat dibayangkan hasil sebuah pekerjaan yang dikerjakan tergesa-gesa, hal ini paradox dengan motto kurikulum 2013 yang berbasis "science", dan jika dicermati buku-buku yang diproduksi secara sentralistik,

21 Desyandri, “Evaluasi Kurikulum 2013” https://desyandri.wordpress.com/2014/01/21/evaluasikurikulum-2013 (diakses 14 Februari 2019).

22 Ibid. 
tidak sesuai dengan perbedaan kemampuan, keahlian, dan perbedaan karakteristik masing-masing sekolah. 2) Secara konseptual muatan kurikulum, sosialisasi, dan implementasinya, terdapat muatan yang tidak seimbang antara penguasaan keilmuan dengan tuntutan untuk membangun sikap dan karakter peserta didik. Kurikulum dirancang dengan mengaitkan seluruh bidang keilmuan dengan keagamaan, dan ditambah lagi dengan penguasaan pendidikan moral dan karakter. Hal ini, tentu berdampak pada kurangnya penguasaan kemampuan keilmuan dan terjadinya beberapa persoalan tentang perbedaan penjelasan secara keilmuan dengan religi. Kondisi ini memerlukan pemahaman yang mendalam.

Uraian hakikat Kurikulum 2013 di atas dapat menjadi pertimbangan buat guru PAK di dalam merancang dan melaksanakan evaluasi pembelajaran. Terutama terkait konsep peserta didik sebagai pusat pembelajaran dan kreatifitas guru PAK di dalam mengejewantahkan nilai-nilai kristiani dalam diri peserta didik.

3. Polemik dan Rekomendasi Implementasi Evaluasi Pembelajaran dan Kerikulum 2013

Problematika yang dibahas pada pendahuluan tulisan ini mengungkapkan bahwa ada dua aspek yang menjadi pokok permasalahan. Aspek tersebut terkait permasalahan teoritis dan praktis. Aspek teoritis mempersoalkan munculnya beberapa perbedaan dalam memahami istilah evaluasi pembelajaran. Permasalahan konsep ini penting untuk diselesaikan. Untuk itu, pemapakan secara teoritis hakikat dari evaluasi pembelajaran dan Kurikulum 2013 diharapkan dapat membantu guru-guru PAK dalam memahami kedua konsep tersebut. Sehingga tidak keliru dalam memahami dan melaksanakannya.

Berikutnya adalah permasalahan aspek praktis. Aspek praktis mempersoalkan guru-guru PAK dalam mengaplikasikan dan mengejewantahkan evaluasi pembelajaran belum sesuai dengan ketentuan dan kaidah yang berlaku pada Kurikulum 2013. Uraian teoritis yang membahas hakikat evaluasi pembelajaran dan Kurikulum 2013 di atas diharapkan menjadi pencerah dalam melaksanakan evaluasi pembelajaran. Terlebih terkait proses pembelajaran yang menjadikan peserta didik menjadi pusat pembelajaran. Sasaran utamanya pun terkait penanaman nilai-nilai kristiani dalam sikap dan perilaku peserta didik. Maka pelaksanaan evaluasi pun mengacu pada tujuan tersebut, yaitu mencakup perkembangan kognitif, afektif, dan psikomotorik peserta didik.

Poin penting berikutnya yang perlu diperhatikan oleh seorang guru PAK dalam mengimplementasikan evaluasi PAK dalam Kurikulum 2013 adalah memahami dengan baik penggunaan instrumen evaluasi dalam proses pembelajaran PAK. Instrumen evaluasi merupakan alat yang digunakan untuk mengukur penilaian hasil belajar peserta didik. Menurut teori Benjamin S. Bloom, hasil belajar terdiri atas tiga bagian, yaitu ranah kognitif, afektik, dan psikomotorik.23

Instrumen yang digunakan untuk mengukur hasil belajar ranah kognitif menggunakan teknik tes. Sementara untuk mengukur ranah afektif dan psikomotorik menggunakan teknis non-tes. Keterangan ini diulas oleh Nana Sudjana. Ia menjelaskan bahwa hasil belajar dan proses belajar tidak hanya dinilai oleh tes, baik melalui bentuk tes uraian maupun tes objektif, tetapi juga dapat dinilai oleh alat-alat nontes atau bukan tes. ${ }^{24}$

Instrumen tes adalah suatu teknik atau cara yang digunakan dalam rangka melaksanakan kegiatan pengukuran, yang di dalamnya terdapat berbagai pertanyaan,

${ }^{23}$ Asep Jihad dan Abdul Haris, Evaluasi Pembelajaran (Yogyakarta: Multi Pressindo, 2013), 14.

24 Nana Sudjana, Penilaian Hasil Proses Belajar Mengajar (Bandung: Remaja Rosdakarya, 2013), 
pernyataan, atau serangkaian tugas yang harus dikerjakan atau dijawab oleh peserta didik. ${ }^{25}$ Sedangkan instrumen non-tes ialah suatu teknik atau cara pengukuran perubahan sikap dan pertumbuhan peserta didik. ${ }^{26}$

Instrumen evaluasi tes dan non-tes hasil belajar peserta didik terdapat berbagai jenis. Jenis instrumen tes terdiri atas tes bentuk uraian dan tes bentuk objektif. ${ }^{27}$ Tes bentuk uraian mencakup: uraian terbatas dan uraian bebas. Uraian terbatas merupakan upaya peserta didik mengemukakan hal-hal tertentu sebagai batas-batasnya. Walaupun kalimat jawaban peserta didik itu beraneka ragam, tetap harus ada pokok-pokok penting yang terdapat dalam sistematika jawabannya sesuai dengan batas-batas yang telah ditentukan dan dikehendaki dalam soalnya. Sedangkan uraian bebas ialah peserta didik bebas untuk menjawab soal dengan cara dan sistematika sendiri. Peserta didik bebas mengemukakan pendapat sesuai dengan kemampuan.

Selanjutnya ialah tes bentuk objektif. Tes objektif menuntut peserta didik untuk memilih jawaban yang benar di antara kemungkinan jawaban yang telah disediakan, memberikan jawaban singkat, dan melengkapi pertanyaan atau pernyataan yang belum sempurna. Tes bentuk objektif terdiri atas: benar-salah, pilihan ganda, menjodohkan, dan melengkapi atau jawaban singkat.

Jenis instrumen non-tes terdiri atas: observasi, wawancara, skala sikap, daftar cek, skala penilaian, angket, dan studi kasus. ${ }^{28}$ Jenis observasi adalah suatu proses pengamatan dan pencatatan secara sistematis, logis, objektif, dan rasional mengenai berbagai fenomena, baik dalam situasi yang sebenarnya maupun dalam situasi buatan untuk mencapai tujuan tertentu. Alat yang digunakan dalam melakukan observasi disebut pedoman observasi. Dalam evaluasi pembelajaran, observasi dapat dapat digunakan untuk menilai proses dan hasil belajar peserta didik, seperti tingkah laku peserta didik pada waktu belajar, berdiskusi, mengerjakan tugas, dan lain-lain.

Jenis non-tes wawancara adalah salah satu bentuk alat evaluasi jenis non-tes yang dilakukan melalui percakapan dan tanya jawab, baik langsung maupun tidak langsung dengan peserta didik.Wawancara langsung adalah wawancara yang dilakukan secara langsung antara pewawancara atau guru dengan orang yang diwawancarai atau peserta didik tanpa melalui perantara. Wawancara tidak langsung adalah pewawancara atau guru menanyakan sesuatu kepada kepada peserta didik melalui perantaraan orang lain atau media, tidak menemui langsung kepada sumbernya.

Jenis non-tes skala sikap yaitu suatu kecenderungan tingkah laku untuk berbuat sesuatu dengan cara, metode, teknik, dan pola tertentu terhadap dunia sekitarnya, baik berupa orang-orang maupun berupa objek-objek tertentu. Jenis non-tes daftar cek adalah suatu daftar yang berisi subjek dan aspek-aspek yang akan diamati. Daftar cek dapat memungkinkan guru sebagai penilai mencatat tiap-tiap kejadian yang betapun kecilnya, tetapi dianggap penting. Manfaat daftar cek bagi guru antara lain: membantu guru untuk mengingat-ingat apa yang harus diamati, dan dapat memberikan informasi kepada stakeholder.

Jenis non-tes skala penilaian adalah suatu penilaian fenomena-fenomena yang disusun dalam tingkatan-tingkatan yang telah ditentukan. Jenis non-tes angket yaitu alat untuk mengumpulkan dan mencatat data atau informasi, pendapat, dan paham dalam hubungan kausal yang dilaksanakan secara tertulis dalam bentuk pertanyaan atau pernyataan. Sedangkan jenis non-tes studi kasus adalah studi yang mendalam dan

\footnotetext{
25 Arifin, Evaluasi Pembelajaran: Prinsip, Teknik, dan Prosedur, 118.

26 Ibid., 152.

27 Ibid., 125-135.

${ }^{28}$ Ibid., 152-168.
} 
komprehensif tentang peserta didik, kelas atau sekolah yang memiliki kasus tertentu. Misalnya, peserta didik yang sangat cerdas, sangat lamban, sangat rajin, sangat nakal atau kesulitan dalam belajar. Penekanan studi kasus ialah pada diagnosis masalah-masalah peserta didik dan memberikan rekomendasi untuk mengatasinya.

\section{Kesimpulan}

Pembahasan dalam tulisan ini mengungkapkan bahwa ada dua aspek utama yang disoroti dalam hal tahapan pelaksanaan evaluasi pembelajaran pada Kurikulum 2013. Aspek tersebut adalah aspek teoritis dan praktis. Dalam tahapan awal yaitu aspek teoritis guruguru PAK diharapkan memahami dengan baik hakikat dari evaluasi pembelajaran dan hakikat Kurikulum 2013. Pemahaman ini penting, karena pemahaman yang baik dan tepat akan hakikat evaluasi pembelajaran dan Kurikulum 2013 akan menolong dan memudahkan guru PAK dalam melaksanakan evaluasi pembelajaran dalam proses pembelajaran di kelas. Namun sebaliknya, jika guru PAK tidak memahami dengan baik hakikat evaluasi pembelajaran dan hakikat Kurikulum 2013 dapat dipastikan guru PAK akan mengalami kesulitan dalam merancang dan melaksanakan evaluasi pembelajaran di kelas. Dengan demikian, secara praktis, guru PAK yang memahami hakikat evaluasi pembelajara dan hakikat Kurikulum 2013 akan memudahkan guru PAK dalam merancang dan melaksanakan evaluasi pembelajaran di kelas.

Prinsip penting berikutnya adalah berkaitan dengan tahapan praktis, yaitu pelaksanaan evaluasi pembelajaran. Penjelasan dan pembahasan teoritis dalam tulisan ini mengungkapkan bahwa tahapan utama dan pertama dalam pelaksanaan evaluasi pembelajaran PAK adalah dengan memahami hakikat dari evaluasi pembelajaran itu sendiri. Kemudian memahami dengan baik hakikat dari Kurikulum 2013 yang digunakan dalam suatu proses pembelajaran. Pemahaman yang baik akan kedua hakikat ini menjadi dasar keberhasilan dalam pelaksanaan evaluasi pembelajaran PAK di sekolah. Di samping itu, dalam hal mengimplementasikan dan melaksanakan evaluasi pembelajaran sesuai Kurikulum 2013 ialah memahami dengan baik penggunaan instrumen evaluasi tes dan nontes sebagai teknik penilaian dan pengukuran hasil belajar peserta didik. Inilah beberapa tahapan penting yang perlu diperhatikan dan dicermati oleh seorang guru PAK dalam melaksanakan evaluasi pembelajaran PAK.

\section{Rujukan}

Arifin, Zainal. Modul Evaluasi Pembelajaran. Jakarta: Direktorat Jenderal Pendidikan Islam Kementerian Agama RI, 2012. Rosdakarya, 2016. Evaluasi Pembelajaran: Prinsip, Teknik, dan Prosedur. Bandung: Remaja

Arikunto, Suharsimi. Dasar-dasar Evaluasi Pendidikan Edisi 2. Jakarta: Bumi Aksara, 2012.

Boehlke, Robert R. Sejarah Perkembangan Pemikiran dan Praktek PAK dari Plato sampai Ig. Loyola. Jakarta : BPK Gunung Mulia, 1994.

Jihad, Asep dan Abdul Haris. Evaluasi Pembelajaran. Yogyakarta: Multi Pressindo, 2013.

Kristianto. Prinsip dan Praktik Pendidikan Agama Kristen. Jakarta: BPK Gunung Mulia, 2000.

Nuhamara, Daniel. Pembimbing Pendidikan Agama Kristen. Bandung: Jurnal Info Media, 2009.

Sudjana, Nana. Penilaian Hasil Proses Belajar Mengajar. Bandung: Remaja Rosdakarya, 2013.

Sukardi. Evaluasi Pendidikan: Prinsip dan Operasionalnya. Jakarta: Bumi Aksara, 2011.

Supardi. Kinerja Guru. Jakarta: RajaGrafindo Persada, 2013.

Tayibnapis, Farida Yusuf. Evaluasi Program dan Instrumen Evaluasi. Jakarta: Rineka Cipta, 2008. 
Kemendikbud. Buku Guru Pendidikan Agama Kristen dan Budi Pekerti. Jakarta: Kementerian Pendidikan dan Kebudayaan, 2014.

Jurnal Online:

Wirman Kasmayadi, Kumaidi, dan Sumarno, "Pengembangan Instrumen Asesmen Diri Guru Terhadap Aktivitas Pengembangan Keprofesian Berkelanjutan https://journal.uny.ac.id/index.php/jpep/article/view/8290/10888 (diakses 9 Maret 2019).

Website:

Tuanguru, Evaluasi Bukan Untuk Menghakimi Siswa" http://www.tuanguru.com/2012/07/evaluasi-bukan-untuk-menghakimi-siswa.html (diakses 5 Februari 2019).

Desyandri, "Evaluasi Kurikulum 2013" https://desyandri.wordpress.com/2014/01/21/evaluasikurikulum-2013 (diakses 14 Februari 2019). 